\title{
Motivational factors influencing MSU accounting students to become a certified public account- ant (CPA)
}

\author{
Rahmawati Ulfah $^{a^{*}}$, Adam Amril Jaharadak ${ }^{\mathrm{a}}$ and Abdul Ali Khatibi ${ }^{\mathrm{a}}$
}

${ }^{a}$ Post Graduate Centre, Management and Science University, University Drive, Off Persiaran Olahraga, Section 13, 40100, Selangor, Malaysia

\begin{tabular}{l}
\hline C H R O N I C L E \\
\hline Article history: \\
Received: April 18, 2019 \\
Received in revised format: April \\
282019 \\
Accepted: May 19, 2019 \\
Available online: \\
May 20, 2019 \\
\hline Keywords: \\
Quality motivation \\
Economic motivation \\
Social Motivation \\
Career motivation \\
Certified Public Accountant
\end{tabular}

A B S T R A C T

Public accountants play important role for development of business activities. Malaysia needs as many as 60,000 qualified accountants in year 2020 but only half of the figure is presently achieved. This paper tries to identify motivational factors influencing on accounting students to become Certified Public Accountant (CPA). The objective of this paper is to analyze the influence of Quality Motivation, Economic Motivation, Social Motivation, Career Motivation influencing on CPA qualification. The method of collecting data is questionnaire by using a sample of 85 students at Management and Science University, Malaysia and Smart PLS is used in analyzing this research. The results indicate a positive influence on quality motivation, social motivation, and career motivation on the interest in taking the CPA while economic motivation has no influence on the interest in taking the CPA in this paper. In other words, the factors describe approximately $89 \%$ of the changes of dependent variable (CPA).

\section{Introduction}

There has been a census that Malaysia needs more public accountants to accomplish the mission reaching "Wawasan 2020". According to Bank Negara Malaysia (2014), Malaysian economy was developed significantly in recent years which indicates that the business activities is expanding (Abidin \& Haseeb, 2018). In any case, very few qualified individuals are setting up which might give a signal that a couple of determinants may influence the undergraduate students to proceed to become CPA. Malaysia targeted to have 60,000 of qualified accountants in year 2020 however only half of the target has been accomplished yet. There are around 33,000 in 2018 qualified accountants in Malaysia of which just 8.42 percent are Bumiputras and Malaysia needs to increase the percentage of Bumiputras CPA to 30 percent. According to Byrne et al. (2012) "Students awareness, motivations, and readiness are among the key factors influencing the students' decision in pursuing a professional accounting education". In addition, according to Churchman, (2013) "motives and readiness are also important factors impacting on students learning performance achieved during higher education".

* Corresponding author.

E-mail address: rahmawatiulfah99@gmail.com (R. Ulfah) 


\section{Literature}

\subsection{Quality Motivation}

The quality of a person is influenced both directly and indirectly by the level of education. Elements of quality or competency are things that are highly considered in the accounting profession (Kusumastuti \& Waluyo, 2013). They branded quality in terms of excellence, value, conformance to specifications and meeting (AbuKhalifeh \& Albattat, 2017). According to Thomas et al. (1998), there is a strong relationship between poor quality review results, a low level of continuing professional education, low professional experience, with ethical violations of practice substandard by public accountants. From the description it can be concluded that one's quality is influenced directly or indirectly by the level of education. Employee training and development is any attempt to improve current or future employee performance by increasing an employee's ability to perform (Randall \& Schuler, 1998). Quality motivational of a person is influenced both directly and indirectly by the level of education. The success of the accounting program students in professional examinations is generally used as a good indicator of the quality of accounting education programs.

\subsection{Economic Motivation}

Economic motivation is an impulse that arises in a person to improve his/her abilities to achieve awards financially desired (Widyastuti et al., 2004). Financial awards consist of direct awards such as salary payments, overtime, leave, payment based on performance and indirect awards such as insurance, programs retirement, and so on (Minan, 2011). As in complex human theories, one of the main models of complex human theory is associated with the human economy motivated by financial rewards. According to Maslow's theory, physiological needs are necessity of the most basic to be satisfied to stay alive like food, housing, clothing (Uno, 2014: 41). Therefore the award financial is very important to meet one's needs. Someone's salary is also determined by the level of education and considerable experience (Linda \& Muda, 2011).

\subsection{Social Motivation}

Social is everything related to society and public interest. Interest is the feeling of wanting to give our attention to something or of wanting to be involved with and to discover more about something (Albattat et al., 2016; Bernama, 2014). Social perspective (affiliation or connectedness) according to Santrock adapted by Nurhakim (2015) is a motive to connect with others safely, namely social needs, friends, loved and accepted in the association of employee groups and their environment. In this case, an extrinsically motivated individual will be attracted to what will be obtained in the form of profits, working conditions, interpersonal relationships, and social pressure. If social motivation in a person is high, then there will be an immediate interest in getting the award. The need for cooperation in working groups will increase relationships with other parties. This is because humans want to get recognition, maintain prestige, get pride, have inner (emotional) satisfaction in dealing with others, satisfy themselves with mastery of others and become harmonious. Social motivation factors have positive influence on interest (Mahmud, adapted by Nurhakim, 2015).

\subsection{Career Motivation}

Career motivation is the drive that is in someone to increase its ability in order to achieve position or a better career than before (Widyastuti, 2004). Careers can interpreted as a series of one's work journey throughout life. Work motivation is defined as conditions which evokes, directs and maintains related behaviors with the work environment (Dyastari \& Yadnyana, 2016). Career motivation is an impulse that arises from a person to improve his/her personal abilities in order to achieve a career, then with development of the capabilities that have become better potential than before. Self-actualization is someone's desire to develop his/her potential systematically to become effective and normal abilities in pursuing a career for someone, so career motivation is considered appropriate with the interest of being a public 
accountant by taking the CPA exam, and this is the right choice so that the potential that already exists in the bachelor's degree accounting can be developed.

\subsection{Certified Public Accountants (CPA)}

Accountant profession is a profession that is related to examine or audit, and has a more general understanding because it includes various types of checks such as audit management, internal audit, governmental audit, including financial or general / financial audit. One examination that provides general audit services is the work of a public accountant. A public accountant is an accountant who obtains permission from the finance minister to examine public accounting services in Malaysia and the absolute requirement to work as a public accountant is to pass the CPA of Malaysia exam. The absolute requirement for becoming a public accountant must be a Certified Public Accountant (CPA) degree. CPA is a certification for the profession of public accountants or financial report auditors. CPA has difficult qualifications and exams and CPA of Malaysia exams is one part of the certification process for someone who will get a license as a public accountant in Malaysia.

\section{Research Methodology}

Fig. 1 describes the proposed method of this paper to examine the hypotheses of the survey.

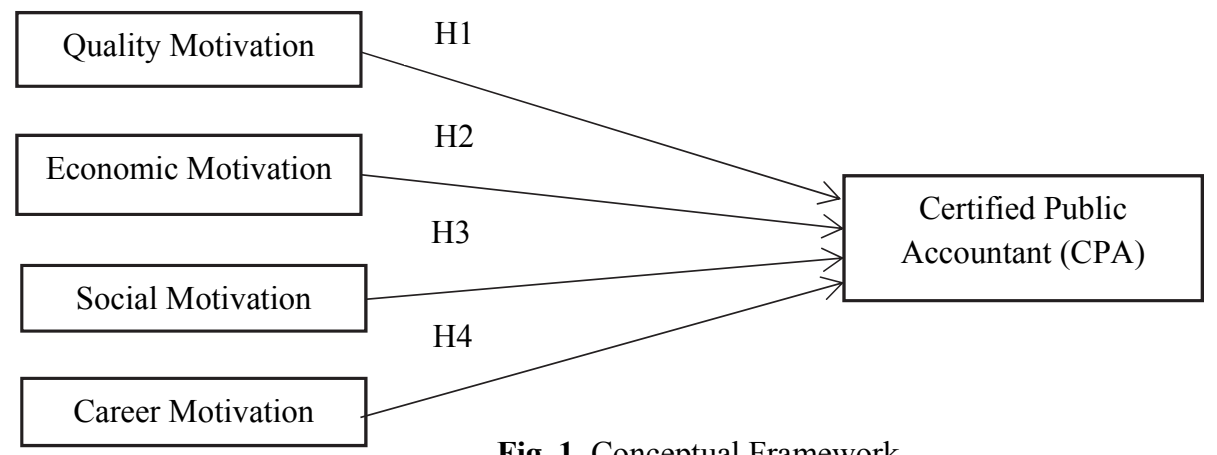

Fig. 1. Conceptual Framework

Based on the conceptual framework in Fig. 1, the research hypotheses in this study can be determined as follows:

$\mathrm{H}_{1}$ : Quality motivation has a positive effect on accounting students to become a CPA.

$\mathrm{H}_{2}$ : Economic motivation has a positive effect on accounting students to become a CPA.

$\mathrm{H}_{3}$ : Social motivation has a positive effect on accounting students to become CPA.

$\mathrm{H}_{4}$ : Career motivation has a positive effect on accounting students to become CPA.

The proposed study of this paper is analyzed by Structural Equation Modeling (SEM). There are two kinds of models of SEM, the covariance-based SEM and SEM-based variants or components that are popularly known as Partial Least Square (PLS) (Ghozali, 2012). LISREL (Linear Structural Relationship) is the only SEM program that is advanced and can estimate the problems that is almost impossible to do by other programs, such as: AMOS, EQS, etc. Besides, LISREL is the most informative program in presenting statistical results (Ghazali and Fuad, 2012: 3).

\subsection{Outer Model}

The outer model is an assessment of the validity and reliability that connects the indicators with other variables. There are three ways to assess the measurement model including convergent validity, discriminant validity, and composite reliability. Construct validity was examined from two perspectives, unidimensionality and discriminant validity and evaluated through factor analysis (Tarofder et al., 2010). The measurement model with the reflective indicator is judged by correlation between the score item / component score with the construct score calculated by the PLS. Convergence validity indicator test is valid using standard loading factor value greater than 0.70 . Communality means the degree to which a 
thing corresponds with every single other thing that show higher communalities are better (Tham et al., 2018). In addition, the communality value must be greater than 0.50 and the Average Variance Extracted (AVE) value should be above 0.50 (Ghozali, 2012). Measurement model with reflective indicator is assessed based on cross loading construct measurement. If the construct correlation with an item is larger than the size of the other construct, then it shows that the latent construct predicts the size on their block better than the other block size. The composite reliability indicator block measuring a construct can be evaluated by two sorts of composite reliability and Cronbach's alpha. Using the output produced by the PLS, a variable has a high reliability if the value of composite reliability is above 0.70 and Cronbach's alpha is above 0.60 .

\subsection{Inner Model}

Inner model or structural model is evaluated by using R-square for endogenous constructs. In assessing the model with PLS that start by looking at R-square for each latent endogenous variable. The interpretation is the same as the interpretation of the regression. Changes in R-square values can be used to assess the effect of particular exogenous latent variable on endogenous variables.

\subsection{Hypothesis Test}

T-statistical test is a test of the relationship between latent variables hypothesized. The significance of estimated parameters provides very useful information on the relationship between research variables. In hypothesis testing, the level of significance used as the limit for rejecting and accepting the proposed hypothesis is $5 \%$ one tail and $\mathrm{df}=80$ for the model equation ( $\mathrm{df}=\mathrm{n}-\mathrm{k}, \mathrm{n}=$ total sample, $\mathrm{k}=$ total variable) or the $\mathrm{t}$-table is +1.66412 , where if the $\mathrm{t}$-statistic value $<\mathrm{t}$-table (1.66412) then the alternative hypothesis $(\mathrm{Ha})$ will be rejected or in other words accept the null hypothesis (H0).

\section{Discussion of Findings}

The results of the study were collected by distributing questionnaires directly to accountant students in Management and Science University (MSU) Malaysia. The distribution of this questionnaire was conducted from 2 November 2018 to 4 January 2019 with 85 respondents and all filled the questionnaires completely. Characteristics by gender and age from 85 respondents is 34 respondents' gender are male and 51 respondents are female. In terms of age it can be seen that most respondents are aged 22-25 years old with 68 respondents, while others aged 19-21 are 7 respondents, aged more than 25 are 7 respondents, and aged less than 18 only 3 respondents. Characteristics of the last education of respondents, indicate that 55 respondents hold bachelor degree, and 30 respondents hold only Diploma degree.

\subsection{Outer Model}

Fig. 2 demonstrates the results of testing the hypotheses of the survey.

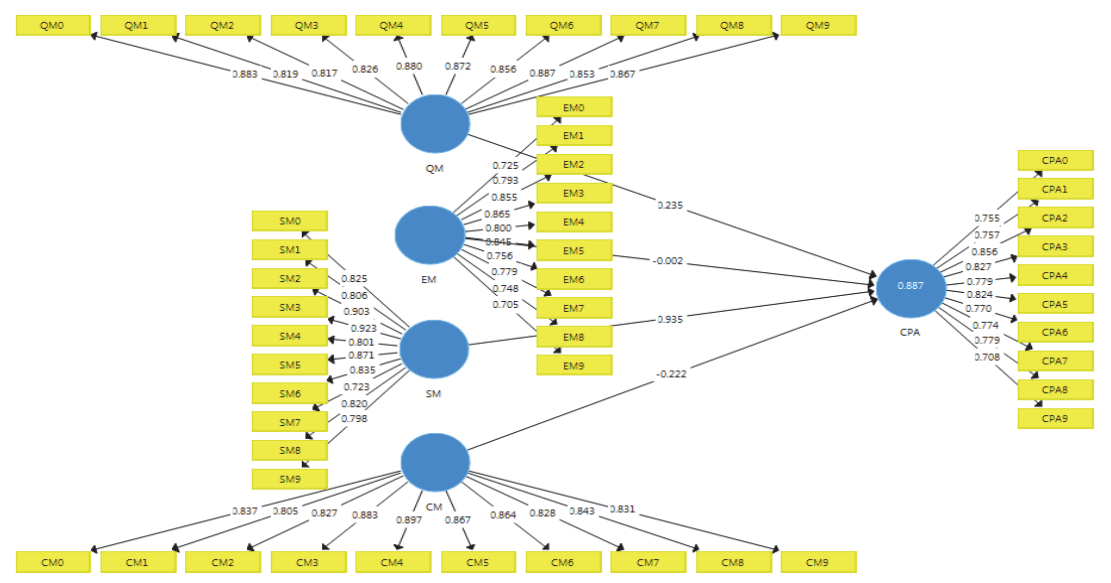

Fig. 2. Outer Model 


\subsection{Convergence Validity Test}

Results of data processing as shown in Fig. 2 show that all constructs have fulfilled convergence validity test, Communality and AVE score are above 0.50 . The test results show that the loading factor value of all constructs is greater than 0.50 . This indicates that all indicators are valid and can be used in subsequent tests (See Table 1).

\section{Table 1}

Convergence Validity Test

\begin{tabular}{llllll}
\hline Variable & CPA & QM & EM & SM & CM \\
\hline AVE \& Communality & 0.614 & 0.733 & 0.622 & 0.693 & 0.720 \\
\hline
\end{tabular}

\subsection{Discriminant Validity Test}

The results of data processing in figure obtained the value of cross loading or correlation between constructs with variables in general already supports the concept of measurement of each variable because it has the largest factor loading compared with the value factor loading to other variables. Thus it can be concluded that all latent constructs predict indicators on their blocks better than other construct.

Table 2

Discriminant Validity Test

\begin{tabular}{|c|c|c|c|c|c|c|}
\hline Indicator & $\begin{array}{c}\text { Certified Public } \\
\text { Accountant }\end{array}$ & Quality Motivation & Economic Motivation & Social Motivation & Career Motivation & Interpretation \\
\hline CPA1 & 0.757 & 0.498 & -0.166 & 0.677 & 0.467 & Valid \\
\hline CPA2 & 0.856 & 0.531 & -0.121 & 0.826 & 0.580 & Valid \\
\hline CPA3 & 0.827 & 0.364 & -0.284 & 0.813 & 0.388 & Valid \\
\hline CPA4 & 0.779 & 0.486 & -0.024 & 0.725 & 0.480 & Valid \\
\hline CPA5 & 0.824 & 0.465 & -0.195 & 0.784 & 0.453 & Valid \\
\hline CPA6 & 0.770 & 0.496 & -0.145 & 0.699 & 0.474 & Valid \\
\hline CPA7 & 0.774 & 0.560 & 0.001 & 0.720 & 0.562 & Valid \\
\hline CPA8 & 0.779 & 0.414 & -0.198 & 0.768 & 0.417 & Valid \\
\hline CPA9 & 0.708 & 0.412 & 0.100 & 0.630 & 0.396 & Valid \\
\hline CPA10 & 0.755 & 0.544 & -0.105 & 0.693 & 0.502 & Valid \\
\hline QM1 & 0.551 & 0.819 & 0.014 & 0.537 & 0.692 & Valid \\
\hline QM2 & 0.533 & 0.817 & 0.036 & 0.522 & 0.687 & Valid \\
\hline QM3 & 0.477 & 0.826 & 0.183 & 0.496 & 0.832 & Valid \\
\hline QM4 & 0.578 & 0.880 & 0.076 & 0.610 & 0.898 & Valid \\
\hline QM5 & 0.553 & 0.872 & 0.122 & 0.607 & 0.916 & Valid \\
\hline QM6 & 0.564 & 0.856 & 0.051 & 0.558 & 0.855 & Valid \\
\hline QM7 & 0.475 & 0.887 & 0.082 & 0.523 & 0.846 & Valid \\
\hline QM8 & 0.424 & 0.853 & 0.173 & 0.427 & 0.805 & Valid \\
\hline QM9 & 0.499 & 0.867 & 0.126 & 0.514 & 0.777 & Valid \\
\hline QM10 & 0.493 & 0.883 & 0.072 & 0.498 & 0.813 & Valid \\
\hline EM1 & -0.050 & 0.246 & 0.793 & -0.073 & 0.269 & Valid \\
\hline EM2 & -0.164 & 0.026 & 0.855 & -0.187 & 0.059 & Valid \\
\hline EM3 & -0.161 & 0.165 & 0.865 & -0.139 & 0.147 & Valid \\
\hline EM4 & -0.064 & 0.142 & 0.800 & -0.084 & 0.120 & Valid \\
\hline EM5 & -0.109 & 0.013 & 0.845 & -0.125 & 0.012 & Valid \\
\hline EM6 & -0.069 & -0.044 & 0.756 & -0.085 & -0.019 & Valid \\
\hline EM7 & -0.042 & 0.082 & 0.779 & -0.044 & 0.077 & Valid \\
\hline EM8 & -0.068 & 0.246 & 0.748 & -0.066 & 0.167 & Valid \\
\hline EM9 & 0.049 & 0.234 & 0.705 & 0.052 & 0.206 & Valid \\
\hline EM10 & 0.006 & 0.053 & 0.725 & 0.019 & 0.813 & Valid \\
\hline SM1 & 0.746 & 0.443 & -0.239 & 0.806 & 0.455 & Valid \\
\hline SM2 & 0.882 & 0.659 & -0.098 & 0.903 & 0.681 & Valid \\
\hline SM3 & 0.870 & 0.526 & -0.263 & 0.923 & 0.526 & Valid \\
\hline SM4 & 0.795 & 0.551 & -0.009 & 0.801 & 0.546 & Valid \\
\hline SM5 & 0.857 & 0.536 & -0.197 & 0.871 & 0.546 & Valid \\
\hline SM6 & 0.794 & 0.553 & -0.104 & 0.835 & 0.578 & Valid \\
\hline SM7 & 0.640 & 0.423 & 0.025 & 0.723 & 0.469 & Valid \\
\hline SM8 & 0.729 & 0.515 & -0.153 & 0.820 & 0.512 & Valid \\
\hline SM9 & 0.499 & 0.867 & 0.126 & 0.798 & 0.502 & Valid \\
\hline SM10 & 0.742 & 0.465 & -0.165 & 0.825 & 0.509 & Valid \\
\hline CM1 & 0.494 & 0.718 & 0.047 & 0.525 & 0.805 & Valid \\
\hline CM2 & 0.473 & 0.790 & 0.235 & 0.463 & 0.827 & Valid \\
\hline CM3 & 0.548 & 0.826 & 0.052 & 0.589 & 0.883 & Valid \\
\hline CM4 & 0.563 & 0.851 & 0.122 & 0.590 & 0.897 & Valid \\
\hline CM5 & 0.564 & 0.856 & 0.081 & 0.569 & 0.867 & Valid \\
\hline CM6 & 0.485 & 0.874 & 0.089 & 0.541 & 0.864 & Valid \\
\hline CM7 & 0.474 & 0.800 & 0.114 & 0.498 & 0.828 & Valid \\
\hline CM8 & 0.497 & 0.765 & 0.011 & 0.590 & 0.843 & Valid \\
\hline CM9 & 0.493 & 0.762 & 0.108 & 0.546 & 0.831 & Valid \\
\hline CM10 & 0.496 & 0.814 & 0.035 & 0.527 & 0.837 & Valid \\
\hline
\end{tabular}




\subsection{Reliability Test}

All variables show values above 0.60 . It can be concluded that all constructs have high reliability.

Table 3

Reliability Test

\begin{tabular}{cccc}
\hline Variable & Composite Reliability & Cronbach Alpha & Interpretation \\
\hline CPA & 0.941 & 0.930 & Reliable \\
QM & 0.965 & 0.960 & Reliable \\
EM & 0.943 & 0.940 & Reliable \\
SM & 0.957 & 0.950 & Reliable \\
CM & 0.963 & 0.957 & Reliable \\
\hline
\end{tabular}

\subsection{Inner Model}

The direction of the regression coefficients all have positive coefficient directions. It is observed that the $\mathrm{R}$-square value for CPA variable is 0.887 , which means CPA can be explained by QM, EM, SM, CM variable of $88.7 \%$. The result shows that Quality Motivation, Economic Motivation, Social Motivation, Career Motivation affect CPA approximately $88.7 \%$.

\subsection{Hypothesis Test}

Hypothesis testing is a test of the relationship between the latent variables hypothesized. The significance of estimated parameters provides very useful information on the relationship between research variables. Table 4 provides estimation output for structural model testing. The result of the testing of structural model (Inner Model) is presented in Table 4 as follows:

Table 4

Hypothesis Test

\begin{tabular}{ccccc}
\hline Hypothesis & Original Sample Estimate & T-Table & T-Statistics & Interpretation \\
\hline $\mathrm{QM} \rightarrow$ CPA & 0.235 & 1.66412 & 2.040 & H1 supported \\
$\mathrm{EM} \rightarrow \mathrm{CPA}$ & -0.002 & 1.66412 & 0.051 & H2 not supported \\
$\mathrm{SM} \rightarrow \mathrm{CPA}$ & 0.935 & 1.66412 & 20.638 & H3 supported \\
$\mathrm{CM} \rightarrow \mathrm{CPA}$ & -0.222 & 1.66412 & 2.380 & H4 supported \\
\hline
\end{tabular}

\subsection{Discussion}

\section{Quality Motivation toward Certified Public Accountants}

$\mathrm{H}_{1}$ : Quality motivation has a positive effect on accounting students to become (CPA).

The test results using SmartPLS 2.0 M3 shows that the Quality Motivation toward CPA has a coefficient value of 0.235 with a $t$ value of 2.040 . The value of $t$-statistics is greater than $t$-table with a significance level of 5\% that is equal to 1.66412 . This means that Quality Motivation has a significant positive influence on CPA. Therefore $\mathbf{H 1}$ is accepted.

\section{Economic Motivation toward Certified Public Accountants}

$\mathrm{H}_{2}$ : Economic motivation has a positive effect on accounting students to become a CPA.

The test results shows that the Economic Motivation toward Certified Public Accountants has value 0.465 with a $t$ value of 2.148. The value of $t$ is less than $t$-table with a significance level of $5 \%$ that is equal to 1.66412. This means that Economic Motivation does not have a significant positive influence on CPA. Thus $\mathbf{H 2}$ is not accepted (reject). 


\section{Social Motivation toward Certified Public Accountants}

$\mathrm{H}_{3}$ : Social motivation has a positive effect on accounting students to become CPA.

The test results shows that the Social Motivation toward Certified Public Accountants has a coefficient value of 0.563 with a $t$ value of 4.578 . The value of $t$ is greater than $t$-table with a significance level of $5 \%$ that is equal to 1.66412 . This means that Social Motivation has a significant positive influence on CPA. Therefore, $\mathbf{H 3}$ is accepted.

\section{Career Motivation toward Certified Public Accountants}

$\mathrm{H}_{4}$ : Career motivation has a positive effect on accounting students to become CPA.

The test results shows that the Career Motivation toward Certified Public Accountants has value of the coefficient of the path of 0,478 with a value of $t$ of 2,215 . The value of $t$ is greater than $t$-table with a significance level of 5\% that is equal to 1.66412 . This means that Career Motivation significantly positively influence toward Certified Public Accountant. Thus H4 is accepted.

\section{Conclusion}

This study has aimed to analyze the effect of quality motivation, economic motivation, social motivation, and career motivation on the interest of accounting students to become CPA. Based on the analysis and discussion in the previous section, the following conclusions can be drawn:

1. The results of the first hypothesis test indicate a positive influence on quality motivation on the interest in taking the CPA. So, by following and passing the CPA, the quality and competence of public accountants continues to grow. In this case, the researcher can provide evidence that quality motivation influences the interest of accounting students in MSU Malaysia to take the CPA.

2. The results of the second hypothesis test show no influence on economic motivation on the interest in taking the CPA. In this case, researchers have not been able to provide evidence that career motivation influences the interest of accounting students in MSU Malaysia to take the CPA.

3. The results of the third hypothesis test indicate a positive effect of social motivation on the interest in taking the CPA. Thus, this study can provide evidence that social motivation influences the interest of accounting students in MSU Malaysia to take the CPA.

4. The results of the fourth hypothesis test indicate a positive effect of career motivation on the interest in taking the CPA. Thus, this study can provide evidence that career motivation influences the interest of accounting students in MSU Malaysia to take the CPA.

\subsection{Implication}

Based on the results of this study it was found that this study had theoretical and practical implications. The theoretical findings of this study can add empirical evidence about the influence of quality motivation theory, career motivation and economic motivation, social motivation to take CPA. The positive influence between quality motivation, social motivation, and career motivation on the interest of accounting students to take CPA shows that motivation can increase someone's interest, especially in the field of education. In addition to the use of motivation as an encouragement for oneself, this research also has practical benefits for MSU. The implication of this research for academic institutions is that it can provide convenience for students such as providing CPA exam scholarship offers if they have graduated with cum laude and obtain work experience because to participate in CPA requires time and money. The benefits of other studies for academic institutions in Malaysia are expected to provide insight into considering appropriate policies to make the profession more attractive to graduates of accountants 
such as cooperating with companies and making the CPA title as one of the priority criteria in admission selection at the company.

\subsection{Contribution}

Contribution for this research is follow as:

1. The results of this study for authors and readers can add knowledge about the factors that influence the interest of accounting students to obtain CPA certification.

2. This study can add empirical evidence regarding the effect of motivation on the interest of accounting students following the CPA and as contribute to the factors that influence the interest of accounting students to obtain CPA certification.

3. Provide additional information and references for educational institutions to determine the steps in increasing the interest of accounting students to participate in CPA in relation to motivation.

\subsection{Recommendation}

Recommendation for this research can be expected as:

1. The results of this study are expected to later be used as a reference for better research in the future regarding the explanation of the factors that influence the interest of accounting students to obtain CPA certification.

2. As input for MSU Malaysia to improve socialization and promotion of the importance of CPA to accounting students, so that more students are interested in participating in the CPA.

3. In addition, this research is expected to be a motivator and consideration for students in making decisions to continue their education even higher.

\subsection{Limitations of Research}

The implementation of this study still has limitations:

1. This study only uses survey methods through distributing questionnaires without conducting direct interviews, so the results of this study only reveal data from the collected instrument results.

2. This study did not conduct discussions and adjustments to the experts of public accountants and CPA regarding questionnaire literature data, because the framework of this questionnaire was developed from the research interests of Chartered Accountants (CA).

\subsection{Research Suggestions}

Based on the limitations of this study, it is expected:

1. Using survey methods through questionnaires and interview techniques directly, so that research data can describe the actual conditions.

2. Conduct a discussion in adjusting the questionnaire literature data to the relevant public accountant experts.

\section{Acknowledgement}

The authors would like to thank the anonymous referees for constructive comments on earlier version of this paper. 


\section{References}

Abidin, I. S. Z., \& Haseeb, M. (2018). Malaysia-Gcc bilateral trade, macroeconomic indicators and islamic finance linkages: A gravity model approach. Academy of Accounting and Financial Studies Journal, 22, 1-7.

AbuKhalifeh A. N., \& Albattat, A.R.. (2017). Using Structural Equation Modelling to Evaluate the Hotel Restaurants' Service Quality Dimensions, Satisfaction and Customer's Loyalty. The 5th Tourism and Hospitality International Conference 2017, 27 September, At MATiC, Kuala Lumpur, Malaysia.

Albattat, A. R., Amir, I. D., \& Muhammad, N. S. N. (2016). Students Awareness towards Traditional Cultural Dances in Sarawak, Malaysia. Almatourism-Journal of Tourism, Culture and Territorial Development, 7(13), 117-128.

Association of Chartered Certified Accountants. (2016). Retrieved July, 2018, from https://www.accaglobal.com/content/dam/ACCA_Global/Technical/smb/pi-sme developmentasean.pdf

Bernama. (2014). Professional Accounting Centre To Be Set Up To Boost Number Of Bumiputra Accountants. http://accountancy.uitm.edu.my/v2/index.php/news-events/news/92-professional-accounting-centre-to-be-set-up-to-boost-number-ofbumiputra-accountants.

Byrne, M., Flood, B., Hassall, T., Joyce, J., Arquero Montaño, J. L., González González, J. M., \& TournaGermanou, E. (2012, June). Motivations, expectations and preparedness for higher education: A study of accounting students in Ireland, the UK, Spain and Greece. Accounting Forum, 36(2), 134-144).

Churchman, R. J. (2013). Attracting the best and brightest: An examination of the factors that influence students' intent to enter the accounting profession. Anderson University.

Dyastari, N. P. S., \& Yadnyana, I. K. (2016). Pengaruh Motivasi Pada Minat Mahasiswa Non Akuntansi Untuk Mengikuti Pendidikan Profesi Akuntansi. E-Jurnal Akuntansi, 333-361.

Ghozali, I. (2012). Aplikasi Analisis Multivariate dengan Program SPSS. Semarang: BP Universitas Diponegoro.

Kusumastuti, R., \& Waluyo, I. (2013). Pengaruh motivasi dan pengetahuan UU No. 5 tahun 2011 tentang akuntan publik terhadap minat mahasiswa akuntansi mengikuti pendidikan profesi akuntansi (PPAk). Nominal, Barometer Riset Akuntansi dan Manajemen, 2(2).

Linda, L., \& Muda, I. (2011). Pengaruh pengetahuan akuntansi dan motivasi terhadap minat mahasiswa akuntansi perguruan tinggi negeri dan swasta di Propinsi Nanggroe Aceh Darusalam untuk mengikuti pendidikan profesi akuntansi (PPAk). Jurnal Keuangan \& Bisnis 3(2), 133-143.

Minan, Ke. (2011). Pengaruh motivasi terhadap minat mahasiswa akuntansi untuk mengikuti pendidikan profesi akuntansi (PPAk). Jurnal Keuangan \& Bisnis 3(1).

Nurhakim, C. S. (2015). Analisis Pengaruh Motivasi Terhadap Minat Mahasiswa Akuntansi Mengikuti Ujian Certified Public Accountant (CPA) Universitas Lampung. Lampung.

Randall, S., \& Schuler, W. (1998). Managing Human Resources 6th Edition. South Western College Publishing. USA.

Tarofder, A. K., Marthandan, G., \& Haque, A. (2010). Critical factors for diffusion of web technologies for supply chain management functions: Malaysian perspective. European Journal of Social Sciences, 12(3), 490-505.

Tham, J., S. M. Ferdous, Azam, \& Sarwar, A. (2018). Determinants of tourist's satisfaction for effective tourism marketing in Sabah, Malaysia: An Empirical Study. European Academic Research 6(8).

Thomas, C. W., Davis, C. E., \& Seaman, S. L. (1998). Quality review, continuing professional education, experience and substandard performance: An empirical study. Accounting Horizons, 12(4), 340.

Uno, H.B. (2014). Teori motivasi \& pengukurannya. 1st ed. Jakarta: Bumi Aksara.

Widyastuti, dkk. (2004). Pengaruh Motivasi terhadap Minat Mahasiswa Akuntansi untuk mengikuti Pendidikan Profesi Akuntansi. Simposium Nasional Akuntansi VII Bali. 
(C) 2019 by the authors; licensee Growing Science, Canada. This is an open access article distributed under the terms and conditions of the Creative Commons Attribution (CCBY) license (http://creativecommons.org/licenses/by/4.0/). 